\title{
PENERAPAN BUSINESS MODEL CANVAS PADA PENGEMBANGAN USAHA GULA AREN: STUDI KASUS DI KABUPATEN SOPPENG SULAWESI SELATAN
}

\author{
Makkarennu ${ }^{1}$, Inda Rahmadani ${ }^{1}$ \\ ${ }^{1}$ Forestry Faculty, Hasanuddin University, Makassar, Indonesia
}

\begin{tabular}{l}
\hline ARTICLE INFORMATION \\
\hline ISSN: $2579-7204$ (Online) \\
ISSN: 0216-4132 (Print) \\
DOI: $10.26487 / j b m i . v 1811.13175$ \\
\hline SUBMISSION TRACK \\
\hline Received: $8^{\text {th }}$ March 2021 \\
Final Revision: $15^{\text {th }}$ June 2021 \\
Available Online: $21^{\text {st }}$ June 2021 \\
\hline KATA KUNCI \\
\hline Gula aren, BMC, SWOT, Strategi
\end{tabular}

\begin{abstract}
ABSTRAK
Gula aren merupakan salah satu produk HHBK yang memiliki peran sangat penting dalam pengembangan HHBK di Indonesia serta dapat menunjang perekonomian masyarakat di sekitar hutan. Desa Mattabulu yang berada di Kecamatan Lalabata, Kabupaten Soppeng, memiliki potensi pengembangan usaha gula aren. Penelitian ini bertujuan untuk mengidentifikasi atau menyusun strategi pemasaran pada Usaha Gula Aren di Desa Mattabulu. Perumusan strategi dilakukan dengan pendekatan Business Model Canvas (BMC), melalui sembilan elemen kunci BMC yakni segmen pelanggan, proporsi nilai, saluran, hubungan pelanggan, arus penerimaan, sumberdaya utama, aktivitas utama, kemitraan utama, dan struktur biaya. Usaha ini masih mempertahankan segmentasi pasar yang sama sejak lama yang hanya bergantung pedagang pengumpul tanpa ada upaya promosi untuk mendapatkan pelanggan baru. Strategi terbaik pada usaha gula aren ini adalah mengubah strategi dengan menangkap peluang pasar, meningkatkan nilai proposinya serta memperluas akses pasar.
\end{abstract}

\begin{tabular}{l}
\hline KEYWORD \\
\hline Palm sugar, BMC, SWOT, Strategy \\
\hline CORRESPONDENCE \\
\hline Phone: +62 821-8959-7928 \\
E-mail: nmakkarennu@ gmail.com
\end{tabular}

ABSTRACT
Palm sugar is one of HHBK products that has a very
important role in the development of HHBK in
Indonesia and can support the economic of rural
communities. Desa Mattabulu in District of Lalabata,
Soppeng Regency, has the potential to develop palm
sugar business. This study aims to identify or develop
marketing strategies in the Palm Sugar Business in
Desa Mattabulu. The formulation of the strategy is
carried out using the Business Model Canvas (BMC)
approach, using nine key elements of BMC namely
customer segments, value proportions, channels,
customer relationships, revenue streams, main
resources, main activities, key partnerships, and cost
structures. This business has maintained the same
market segmentation for a long time, which only
relies on collecting traders without any promotional
efforts to get new customers. The best strategy in this
palm sugar business is to change strategies by
capturing market opportunities, increasing its value
proposition and expanding market access.




\section{PENDAHULUAN}

Aren (Arenga pinnata) adalah jenis tanaman yang sudah dikenal sejak lama oleh karena hampir semua bagian dari pohon aren ini dapat dimanfaatkan dan berkontribusi terhadap pendapatan masyarakat (Mokuna dkk, 2013). Aren sebagai salah satu produk HHBK memiliki peran sangat penting dalam pengembangan HHBK di Indonesia serta dapat menunjang perekonomian masyarakat di pedesaan dan memiliki pasar yang cerah (Pohan dkk, 2014) serta memiliki permintaan yang tinggi (Makkarennu dkk, 2019)

Kebutuhan gula nasional baik untuk kebutuhan skala rumah tangga maupun skala industry dipengaruhi oleh pertambahan jumlah penduduk Indonesia. Di sisi lain, Kementan (2019) merilis bahwa pemenuhan kebutuhan gula dalam negeri baik untuk konsumsi langsung maupun pasokan kepada industri belum mampu dipenuhi sehingga dipasok dari impor. Tercatat impor gula nasional mengalami peningkatan dimana pada tahun 2014 impor gula sebesar 2,97 juta ton menjadi 5,03 juta ton pada tahun 2018 (Dianpratiwi dkk, 2020)

Salah satu desa di Kabupaten Soppeng yang memiliki potensi pengembangan usaha gula aren adalah Desa Mattabulu yang berada di Kecamatan Lalabata. Di wilayah ini terdapat beberapa kelompok tani yang memproduksi dan menjual gula aren ini. Namun demikian, usaha ini belum dapat berkembang oleh karena model usaha yang dilakukan masih dikelola secara tradisional (Pontoh, 2014) baik pada proses produksi maupun pemasarannya. Haris dkk (2020) juga mengemukakan bahwa pengusahaan gula aren dilakukan hanya untuk memenuhi kebutuhan sehari hari. Oleh karena itu perlu dilakukan suatu upaya untuk mengidentifikasi atau menyusun strategi pemasaran usaha gula aren.

Beberapa cara yang dapat digunakan untuk menyusun strategi pemasaran di antaranya melalui analisis pengembangan pasar, Bussines Model Canvas (BMC), marketing mix, SWOT, IFAS, EFAS adalah metode untuk mengenali kekuatan, kelemahan, peluang, dan ancaman yang berpengaruh pada kelangsungan usaha ini. Melalui pendekatan BMC, model bisnis digambarkan dalam lembar kanvas berisi 9 (sembilan) elemen untuk menggambarkan model bisnis yang sedang dilakukan. Model bisnis ini menggambarkan alasan bagaimana suatu organisasi atau unit usaha dapat menciptakan, memberikan dan menangkap nilai (Osterwalder dan Pigneur, 2015). 
Berdasarkan uraian di atas, penelitian ini bertujuan untuk mengidentifikasi bisnis model yang diterapkan serta menyusun strategi usaha melalui pendekatan $B M C$ yang diintegrasikan dengan analisis SWOT dan Internal Factors Analysis Summary (IFAS) serta External Factors Analysis Summary (EFAS) pada usaha gula aren di Desa Mattabulu, Kecamatan Lalabata Kabupaten Soppeng. Wilayah ini dipilih sebagai lokasi penelitian karena masyarakat menggantungkan harapan hidupnya pada usaha gula aren ini. Dengan demikian diharapkan melalui strategi usaha ini maka usaha gula aren dapat berkembang yang pada akhirnya dapat berkontribusi dalam upaya pemenuhan kebutuhan gula nasional serta berkontribusi pada peningkatan pendapatan masyarakat pengelola usaha gula aren.

\section{TINJAUAN PUSTAKA}

\section{A. Aren}

Tanaman aren memiliki potensi yang melimpah di Indonesia dan sebagian besar tumbuh sebagai hutan campuran dimana aren digunakan sebagai bahan baku pembuatan gula. Aren memiliki nilai ekonomi yang cukup tinggi oleh karena hampir semua bagian dari tanaman ini dapat dimanfaatkan di antaranya buah, batang, nira (Lempang, 2012). Proses produksi gula aren masih sangat tradisional sehingga mempunyai mutu yang sangat beragam (Pontoh, 2013). Gula aren telah dikenal sejak lama sebagai bahan pemanis makanan maupun minuman, penambah aroma dan warna yang dapat dijadikan sebagai pengganti penggunaan gula pasir (Soekarto dkk, 2010). Salah satu keunggulan gula merah dibandingkan gula pasir adalah tekstur yang dihasilkan pada makanan menjadi lebih empuk. Disisi lain, pemanfaatan pohon memiliki kontribusi tidak hanya secara ekonomi semata tetapi juga memberikan dampak sosial dalam hal penyerapan tenaga kerja serta dapat menumbuhkan usaha skala rumah tangga di tingkat petani. Selain itu, pengelolaan, pemanfataan pohon aren ini dapat memberikan nilai tambah produk melalui diversifikasi produk yang dihasilkan yang pada akhirnya dapat memberikan penghasilan bagi masyarakat yang menggelutinya (Mariati, 2013).

\section{B. Bussines Model Canvas (BMC)}

BMC atau juga dikenal dengan istilah Bussines Model Canvas adalah suatu metode utuk mengenal lebih detail rupa usaha yang sedang atau yang akan di jalani dalam satu 
lembar kanvas yang berisi rencana bisnis dengan sembilan elemen kunci yang terintegrasi satu sama lain dan didalamnya mencakup strategi internal maupun eksternal suatu unit usaha. BMC adalah bahasa yang sama untuk menggambarkan, memvisualisasikan, menilai serta mengubah model bisnis sesuai dengan kondisi suatu organisasi (Osterwalder \& Pigneur, 2015). Terdapat sembilan blok yang ada di dalam Model Bisnis Kanvas yaitu; hubungan kemitraan, aktivitas utama, proporsi nilai, sumberdaya utama, segmen pelanggan, hubungan pelanggan, saluran struktur biaya dan arus pendapatan.

\section{Analisis SWOT}

Analisis SWOT mencakup upaya-upaya untuk mengenali kekuatan, kelemahan, peluang, dan ancaman yang dapat menentukan kinerja pada suatu unit usaha atau organisasi. Informasi eksternal perusahaan yang mencakup peluang dan ancaman dapat diperoleh dari berbagai sumber yakni konsumen, pemasok dan kebijakan pemerintah (Daft, 2010). Selain itu, Gurel dan Merba (2017) juga mengemukakan bahwa dengan melakukan analisis ekternal, perusahaan dapat mengidentifikasi ancaman dan peluang kritis untuk melihat lingkungan pesaingnya.

\section{METODE PENELITIAN}

Penelitian dilaksanakan di Desa Mattabulu, Kecamatan Lalabata, Kabupaten Soppeng, Provinsi Sulawasi Selatan. Desa Mattabulu terletak di Kecamatan Lalabata Kabupaten Soppeng, Propinsi Sulawesi Selatan. Desa ini terletak di pegunungan dan mempunyai luas hamparan wilayah 5000 ha $\left(50 \mathrm{~km}^{2)}\right.$ yang terdiri atas lahan pemukiman dan lahan pertanian maupun perkebunan. Jarak antara pusat desa dengan ibu kota kabupaten dengan perjalanan darat kurang lebih dari $15 \mathrm{~km}$ dengan jalan poros desa yang beraspal dengan kondisi rusak. Desa Mattabulu merupakan desa yang memiliki potensi untuk usaha kehutanan, perkebunan dan pariwisata. Wilayah ini berada $4^{\circ} 21^{\prime} 48$,' LS dan $119^{\circ}$ 49'10,'BT-4²2’00” 11949’15 BT. Jumlah penduduk dilokasi ini sebanyak 1.690 Jiwa serta kepadatan penduduk sebesar 33 jiwa per Km. Desa ini terbagi menjadi 4 RW dan 8 RT, tersebar dalam 2 Dusun yaitu Dusun Cirowali dan Dusun Teppoe. Sebagian besar mesyarakat Desa Mattabulu berprofesi sebagai petani. Selain itu, beberapa diantaranya 
bekerja sebagai buruh tani, pedagang, Peternak, tenaga medis, PNS, dan tenaga buruh (Kantor Desa Mattabulu, 2018).

Metode pengambilan data dilakukan dengan menggunakan pendekatan partisipatif dengan teknik observasi (pengamatan langsung pada kegiatan produksi dan pemasaran gula aren), wawancara dengan menggunakan pedoman wawancara untuk memperoleh gambaran terkait dengan model usaha gula aren yang dijalankan, studi literatur (pengumpulan data-data sekunder yang terkait dengan penelitian. Sumber data pada penelitian ini ada dua yaitu data primer dan data sekunder dimana data primer diperoleh dari hasil observasi, wawancara kepada petani aren, ketua dan anggota Kelompok Tani Mattabulu. Data Sekunder bersumber dari laporan penelitian, buku teks, dan jurnal. Data sekunder yang diperoleh yaitu keadaan umum lokasi penelitian dan keadaan sosial ekonomi masyarakat Desa Mattabulu serta faktor-faktor eksternal yang mempengaruhi usaha gula aren.

Analisis data dilakukan secara kualitatif dan kuantitatif. Data kemudian dianalisis dengan menggunakan analisis BMC dan analisis SWOT. Analisis BMC digunakan untuk mengidentifikasi model bisnis gula aren pada Kelompok Tani di Desa Mattabulu di lakukan melalui analisis BMC pada Sembilan elemen kunci yaitu segmen pelanggan, proposisi nilai, saluran, hubungan pelanggan, arus pendapatan, sumber daya utama, aktivitas utama, hubungan kemitraan, dan struktur biaya. Sementara analisis SWOT digunakan untuk mengidentifikasi faktor internal dan eksternal usaha gula aren dilakukan melalui Analisis SWOT pada sembilan elemen kunci BMC.

Menurut Fahmi (2013) dalam melakukan analisis dengan menggunakan SWOT, maka perlu melihat faktor eksternal dan internal sebagai bagian penting dalam analisis SWOT. Sebelum sampai pada tahap matriks SWOT, terlebih dahulu harus mengumpulkan informasi terkait faktor internal perusahaan yang berguna untuk mengetahui apa saja kekuatan dan kelemahan yang dimiliki perusahaan. Adapun tahapan dalam pembentukan Matriks IFAS merujuk pada Rangkuti (2016):

1. Mengidentifikasi faktor kekuatan dan kelemahan pada unit usaha gula aren yang digeluti masyarakat.

2. Memberikan bobot pada masing-masing faktor kekuatan dan kelemahan dengan skala nilai 1,0 (paling penting) sampai 0,0 (tidak penting), berdasarkan pengaruh 
faktor-faktor kekutaan dan kelemahan terhadap posisi strategi usaha guka aren. Jumlah bobot pada masing-masing faktor tersebut tidak lebih dari nilai skor total 1,00 .

3. Menghitung rating pada masing-masing faktor kekuatan dan kelemahan dengan memberikan skala mulai dari 4 (outstanding) sampai dengan 1 (poor), berdasarkan dari pengaruh faktor kekuatan dan kelemahan tersebut terhadap kondisi usaha gula aren yang digeluti masyarakat.

4. Mengalikan jumlah bobot dengan rating, untuk memperoleh faktor pembobotan nilai skor.

5. Menjumlahkan nilai skor yang diperoleh pada nomor 4 tersebut di atas untuk mendapatkan total skor pembobotan pada unit usaha gula aren.

Setelah mendapatkan hasil dari matriks IFAS, kegiatan selanjutnya adalah menemukan faktor-faktor eksternal (peluang dan ancaman) pada unit usaha gula yang digeluti masyarakat. Tahapan dalam penentuan Matriks EFAS merujuk pada Rangkuti (2016) seperti berikut ini:

1. Mengidentifikasi faktor peluang dan ancaman pada unit usaha gula aren yang digeluti masyarakat.

2. Memberikan bobot pada masing-masing faktor peluang dan ancaman dengan nilai mulai dari 1,0 (sangat penting) sampai dengan 0,0 (tidak penting).

3. Menghitung rating pada masing-masing faktor peluang dan ancaman dengan nilai skala mulai dari 1 (poor) sampai dengan 4 (outstanding).

4. Mengalikan jumlah bobot dengan rating untuk memperoleh faktor pembobotan nilai skor.

5. Menjumlahkan nilai skor yang diperoleh pada nomor 4 tersebut di atas untuk mendapatkan nilai total skor pembobotan pada unit usaha gula aren. 


\section{HASIL DAN DISKUSI}

\section{A.Identifikasi Model Bisnis Awal (Existing model)}

Pada umumnya masyarakat yang tinggal di Desa Mattabulu, Kecamatan Lalabata berprofesi sebagai petani aren. Sumber pendapatan utama pada masyarakat di desa tersebut adalah hasil jualan gula aren namun usaha gula aren yang dijalankan pada masyarakat di desa tersebut masih terbilang tradisional mulai dari proses penyadapan, pemasakan, pengemasan, sampai pada proses pemasaran. Berikut dijelaskan elemen elemen BMC:

\section{Segmen Pelanggan}

Segmen pelanggan pada usaha gula aren adalah konsumen lokal dan pengepul besar. Konsumen lokal merupakan konsumen yang membeli gula aren dan berdomisili di daerah tersebut. Konsumen lokal membeli gula aren untuk dikonsumsi sendiri, sebagian untuk dipakai sendiri dan sebagian lainnya digunakan untuk membuat kue yang akan dijual di sekitar tempat tinggal mereka. Pengepul besar merupakan pedagang yang akan membeli produk gula aren yang nantinya akan dijual kembali atau akan dibawa ke pasar besar atau pasar kota kemudian pedagang pasar kota merupakan pedagang yang berjualan langsung ke konsumen yang ada dikota.

\section{Proposisi Nilai}

Rantai pasar dari usaha gula aren ini masih terbilang sederhana. Sebagian besar petani aren hanya mengandalkan pedagang pengumpul dalam memasarkan atau menjual hasil produksi gula aren yang telah dihasilkan. Adapun proposisi nilai atau nilai yang ditawarkan pada usaha gula aren adalah gula aren yang dihasilkan berasal dari bahan organik (tanpa pengawet kimia) yang tentunya aman bagi kesehatan dan tidak berbahaya untuk dikonsumsi.

\section{Saluran}

Saluran yang digunakan oleh petani gula aren dalam menjalankan usahanya ada dua yaitu melalui pedagang pengumpul dan penjualan langsung kepasar. Sebagian besar distribusi produk yang dihasilkan akan melalui pedagang pengumpul atau tidak langsung ke konsumen akhir. Sebagian kecil petani gula aren yang ada di Desa 
Mattabulu melakukan pemasaran atau menjual produk hasil gula arennya langsung kepasar dan konsumen lokal merupakan konsumen akhir yang akan membeli produk gula aren untuk dikonsumsi sendiri. Proses pemasaran produk gula aren kelompok ini masih terbilang tradisional petani aren belum dapat memanfaatkan teknologi informasi seperti yang ada online marketing.

\section{Hubungan Pelanggan}

Hubungan pelanggan yang dibangun dalam usaha gula aren adalah menjalin hubungan personal antara penjual dan pembeli dalam hal ini antara pedagang pengumpul dan pembeli langsung hubungan personal yang terjadi berupa adanya tingkat kepercayaan pembuat gula aren dan para pelanggannya. Kepuasan yang dirasakan oleh pelanggan adalah salah satu tujuan utama dari suatu unit usaha. Oleh karena itu, pihak produsen harus memberikan pelayanan terbaik bagi pelanggannya. Hubungan pelanggan merupakan salah satu untuk melihat sejauhmana hubungan antara pihak produsen dan pelanggannya. Hal ini juga berlaku pada usaha gula aren di lokasi penelitian

\section{Arus Penerimaan}

Petani aren di Desa Mattabulu memperoleh pendapatan dari penjualan langsung ke pedagang pengumpul sebanyak 1000 biji gula perbulan tergantung dari banyaknya nira yang disadap dan penjualan langsung kepasar. Pendapatan yang diperoleh berupa hasil jual gula aren ke pedagang pengumpul yang dijual dengan harga berkisar antara Rp1.500 - Rp2.000 perbuah dengan ukuran kecil sedangkan harga penjualan langsung ke pasar sebesar Rp2.500-Rp3.000. Jumlah penerimaan dari hasil penjualan gula aren melalui pedagang pengumpul sebesar Rp1.500.000 perbulan, atau sebesar Rp18.000.000 pertahun. Dengan demikian, setelah dikurangi dengan biaya-biaya yang dikeluarkan termasuk biaya peralatan (Rp591.000), maka pendapatan yang diterima oleh pembuat gula sebesar Rp17.409.000 per tahun. Arus penerimaan atau revenue streams merupakan pendapatan yang diperoleh oleh pihak pengolah gula aren dari pelanggannya.

\section{Sumber Daya Utama}

Sumber daya utama yang diperlukan dalam menjalankan produksi gula aren adalah bahan baku (nira dari pohon aren), peralatan kerja, tenaga kerja. Tanaman aren yaitu 
bahan baku utama berupa nira aren yang diproduksi menjadi gula aren. Peralatan kerja seperti wajan, cetakan, baskom, penyaring, pengaduk, tungku, bumbung, jerigen, tatakan, parang merupakan peralatan yang digunakan dalam produksi gula aren. Tenaga kerja merupakan orang-orang yang memiliki keahlian dalam menjalankan proses produksi gula aren yang terdiri dari penyadap nira aren kemudian pembuat gula aren (pemasak nira aren). Semua sumberdaya tersebut sangat penting untuk menghasilkan produk gula aren.

\section{Aktivitas Utama}

Proses pembuatan gula aren di Desa Mattabulu dilakukan dengan beberapa tahapan yakni, dimulai dari proses penyadapan nira aren, pemasakan nira menjadi gula, pencetakan, pengemasan dan penjualan. Penyadapan nira yang dilakukan oleh pembuat gula aren dimulai pukul 07.00 pagi hingga pukul 05.00 sore. Sementara itu, proses pemasakan nira menjadi gula dilakukan dua kali proses pemasakan, yang pertama pada saat setelah pengambilan nira sore yang dimasak agar tidak berubah rasa menjadi tuak, lalu dilanjutkan dimasak selama 4 jam bersama hasil sadapan nira di pagi hari. Pencetakan dan pengemasan dilakukan keesokan harinya, setelah nira telah menjadi gula aren dicetak dalam cetakan khusus berbentuk kristal, lalu setelah kering akan dibungkus menggunakan daun tarra (Artocarpus). Proses pengolahan masih dilakukan secara tradisional sebagaimana yang dilakukan secara turun temurun. Belum ada sentuhan tehnologi baik pada saat pengambilan nira, maupun dalam proses produksinya.

\section{Kemitraan Utama}

Kemitraan merupakan hubungan antara pemasok dan produsen yang membuat model bisnis tetap berjalan (Makkarennu dkk, 2019). Kemitraan yang terbangun dalam usaha gula aren ini khususnya pada Desa Mattabulu adalah hubungan pembeli-pemasok untuk menjamin pasokan baha baku berupa nira aren yang dapat diandalkan. Sampai saat ini kemitraan yang terbangun hanya pada konsumen dan produsen, tidak ada mitra yang terbangun antara pemilik lahan dengan yang lainnya karena yang mengambil atau menyadap nira aren adalah pemilik lahan itu sendiri. Kelompok tani ini belum melakukan kemitraan dengan pemerintah hal ini disebabkan belum adanya kerja sama yang dilakukan antara petani dan pemerintah. 


\section{Struktur Biaya}

Biaya yang dikeluarkan oleh pembuat gula aren di Desa Mattabulu peralatan yang digunakan saat penyadapan nira dan pada saat pemasakan nila menjadi gula aren. Beberapa peralatan di antaranya adalah wajan, cetakan, baskom, penyaring, pengaduk, tungku, bumbung, jerigen, tatakan, parang, tali. Analisis SWOT

Perumusan strategi pengembangan usaha gula aren memiliki langkah-langkah yang terstruktur setelah mengidentifikasi elemen-elemen model bisnis awal pada petani aren. Tahap selanjutnya adalah menganalisis informasi terkait faktor-faktor internal dan faktor-faktor eksternal pada ke 9 (sembilan) elemen BMC dengan menggunakan analisis SWOT. Analisis SWOT terdiri dari kekuatan (Streghts), kelemahan (Weakness), peluang (Opportunity), dan ancaman (Threats).

\section{Faktor Internal}

Berdasarkan hasil analisis yang dilakukan terhadap kekuatan dan kelemahan dari kesembilan elemen BMC yang terdapat pada usaha gula aren, maka didapatkan hasil sesuai dengan Tabel 1.

Tabel 1. Faktor Internal Terhadap Elemen BMC

\begin{tabular}{lll}
\hline Elemen BMC & Faktor Internal & Kelemahan (W) \\
\cline { 2 - 3 } Segmen Pelanggan (SP) & Kekuatan (S) & $\begin{array}{l}\text { Belum memenuhi permintaan } \\
\text { konsumen dengan tepat }\end{array}$ \\
\hline Proporsi nilai (PN) & $\begin{array}{l}\text { Hasil produk tidak menggunakan bahan } \\
\text { kimia berbahaya }\end{array}$ & $\begin{array}{l}\text { Kemasan yang digunakan belum } \\
\text { memiliki label dan tidak menarik }\end{array}$ \\
\hline Saluran (SL) & Biaya pemasaran rendah & Saluran Pemasaran belum maksimal \\
\hline Hubungan Pelanggan (HP) & $\begin{array}{l}\text { Hubungan personal yang baik antara } \\
\text { petani gula aren dan pedagang pengumpul }\end{array}$ & $\begin{array}{l}\text { Jangkauan pemasaran hanya } \\
\text { mencakup pada pedagang } \\
\text { pengumpul (sangat bergantung pada } \\
\text { pedagang pengumpul) }\end{array}$ \\
\hline Arus Pendapatan (AP) & $\begin{array}{l}\text { Proses penjualan gula aren yang dilakukan } \\
\text { kepedagang pengumpul ke pembeli } \\
\text { langsung sangat lancar }\end{array}$ & $\begin{array}{l}\text { Petani aren hanya bergantung pada } \\
\text { hasil penjualan gula aren }\end{array}$ \\
\hline Sumberdaya Utama (SU) & $\begin{array}{l}\text { Banyaknya tenaga kerja yang tersedia } \\
\text { Struktur Biaya (SB) }\end{array}$ & $\begin{array}{l}\text { Kurangnya pengetahuan dan } \\
\text { wawasan SDM }\end{array}$ \\
\hline Aktivitas Utama (AU) & $\begin{array}{l}\text { Proses pengelolaan gula aren yang } \\
\text { dilakukan secara berkelanjutan }\end{array}$ & $\begin{array}{l}\text { Masih menggunakan alat tradisonal } \\
\text { dalam pembuatan gula aren }\end{array}$ \\
\hline Hubungan Kemitraan (HK) & $\begin{array}{l}\text { Interaksi atau hubungan personal antara } \\
\text { pembuat aren dan pemilik lahan cukup } \\
\text { baik }\end{array}$ & $\begin{array}{l}\text { Harga hanya dapat ditentukan oleh } \\
\text { pedagang }\end{array}$ \\
\hline
\end{tabular}




\begin{tabular}{lll}
\hline Elemen BMC & Faktor Internal & \\
\cline { 2 - 3 } & Kekuatan $(\mathbf{S})$ & Kelemahan $(\mathbf{W})$ \\
\hline $\begin{array}{l}\text { pembuatan gula aren masih minim karena } \\
\text { masih menggunakan atau memanfaatkan } \\
\text { bahan baku yang tersedia di dalam }\end{array}$ & bahan baku yang tersedia dialam \\
\hline
\end{tabular}

\section{Faktor Eksternal}

Berdasarkan atas hasil analisis yang dilakukan oleh peneliti terhadap peluang dan ancaman dari kesembilan elemen BMC yang terdapat pada usaha gula aren, maka di dapatkan hasil sesuai dengan Tabel 2.

Tabel 2. Faktor Eksternal Terhadap Elemen BMC

\begin{tabular}{|c|c|c|}
\hline \multirow[t]{2}{*}{ Elemen BMC } & \multicolumn{2}{|c|}{ Faktor Eksternal } \\
\hline & Peluang (O) & Ancaman (T) \\
\hline Segemen Pelanggan (SP) & $\begin{array}{l}\text { Tingkat konsumsi masyarakat terhadap } \\
\text { produk meningkat }\end{array}$ & Masuknya pesaing baru \\
\hline Proposisi Nilai (PN) & $\begin{array}{l}\text { Masyarakat sadar akan pola hidup sehat } \\
\text { dengan mengonsumsi produk gula aren } \\
\text { berbahan alami }\end{array}$ & $\begin{array}{l}\text { Produk sejenis yang lebih bagus dan } \\
\text { berkualitas }\end{array}$ \\
\hline Saluran (SL) & $\begin{array}{l}\text { Berkembangnya teknologi komunikasi } \\
\text { yang memudahkan dalam melakukan } \\
\text { kemitraan dan berkomunikasi }\end{array}$ & $\begin{array}{l}\text { Mitra dapat beralih kepembuat gula } \\
\text { aren yang lain dikarenakan } \\
\text { berkembangnya teknologi } \\
\text { komunikasi }\end{array}$ \\
\hline Hubungan Pelanggan (HP) & $\begin{array}{l}\text { Kepuasan pelanggan terhadap produk } \\
\text { akan menarik lebih banyak pelanggan } \\
\text { baru }\end{array}$ & $\begin{array}{l}\text { Ketidakpuasan pelanggan terhadap } \\
\text { hasil produksi }\end{array}$ \\
\hline Arus Pendapatan (AP) & $\begin{array}{l}\text { Permintaan konsumen terhadap gula aren } \\
\text { yang semakin tinggi }\end{array}$ & Banyaknya pesaing \\
\hline Sumberdaya Utama (SU) & $\begin{array}{l}\text { Kebijakan pemerintah dalam melakukan } \\
\text { peningkatan kapasitas terhadap } \\
\text { masyarakat pembuat gula aren }\end{array}$ & $\begin{array}{l}\text { Tidak adanya peremajaan tanaman } \\
\text { aren (petani hanya bergantung pada } \\
\text { tanaman aren yang tumbuh secara } \\
\text { alami) }\end{array}$ \\
\hline Aktivitas Utama (AU) & $\begin{array}{l}\text { Teknologi pengelolaan pasca panen cukup } \\
\text { tersedia }\end{array}$ & Jumlah pesaing yang cukup tinggi \\
\hline Hubungan Kemitraan (HK) & $\begin{array}{l}\text { Adanya kebijakan pemerintah terkait } \\
\text { kemitraan dengan kelompok tani }\end{array}$ & $\begin{array}{l}\text { Belum ada kemitraan dengan } \\
\text { pemerintah setempat }\end{array}$ \\
\hline Struktur Biaya (SB) & $\begin{array}{l}\text { Penggunaan teknologi tepat guna untuk } \\
\text { skala komersil dan teknologi packing akan } \\
\text { meningkatkan kualitas dan kuantitas } \\
\text { produk gula aren }\end{array}$ & $\begin{array}{l}\text { Dengan menggunakan peralatan } \\
\text { pendukung maka akan meningkatkan } \\
\text { biaya-biaya yang nantinya akan } \\
\text { berpengaruh pada pendapatan }\end{array}$ \\
\hline
\end{tabular}

\section{B. Analisis Strategi Pengembangan Usaha Gula Aren}

Tahap-tahap dalam menyusun Tabel Internal Factor Analysis Summary (IFAS) dan Ekstenal Factors Analysis Summary (EFAS) adalah dengan menentukan bobot masing- 
masing faktor dari skala mulai dari 0,00 sampai dengan 1,00 dimana semua bobot tersebut jumlahnya tidak melebihi skor total 1,00. Sedangkan rating dinilai dengan skala mulai dari 4 (outstanding) sampai dengan 1 (poor). Gurel dan Merba (2017) juga mengemukakan bahwa dengan melakukan analisis ekternal, perusahaan dapat mengidentifikasi ancaman dan peluang kritis untuk melihat lingkungan pesaingnya. Penentuan skor pada faktor-faktor strategi internal dapat dilihat dari Tabel 3 dan penentuan skor pada faktor-faktor strategi eksternal dapat dilihat dari Tabel 4

Tabel 3. Internal Factor Analysis Summary (IFAS)

\begin{tabular}{|c|c|c|c|}
\hline Faktor-faktor Strategi Internal & Bobot & Rating & $\begin{array}{l}\text { Nilai } \\
\text { Skor }\end{array}$ \\
\hline \multicolumn{4}{|l|}{ Kekuatan (S): } \\
\hline Adanya Pembeli yang tetap & 0.05 & 9.33 & 0.46 \\
\hline Hasil produk tidak menggunakan bahan kimia berbahaya & 0.08 & 9.33 & 0.78 \\
\hline Biaya pemasaran rendah & 0.10 & 3.66 & 0.38 \\
\hline $\begin{array}{l}\text { Hubungan personal yang baik antara petani gula aren dan pedagang } \\
\text { pengumpul }\end{array}$ & 0.09 & 7.66 & 0.68 \\
\hline $\begin{array}{l}\text { Proses penjualan gula aren yang dilakukan kepedagang pengumpul } \\
\text { kepembeli langsung sangat lancar }\end{array}$ & 0.12 & 7 & 0.87 \\
\hline Banyaknya tenaga kerja yang tersedia & 0.10 & 8.33 & 0.84 \\
\hline Proses pengelolaan gula aren yang dilakukan secara berkelanjutan & 0.11 & 7 & 0.78 \\
\hline $\begin{array}{l}\text { Interaksi atau hubungan personal antara pembuat aren dan pemilik } \\
\text { lahan cukup baik }\end{array}$ & 0.14 & 8.33 & 1.15 \\
\hline $\begin{array}{l}\text { Pengeluaran yang digunakan dalam proses pembuatan gula aren masih } \\
\text { minim karena masih menggunakan atau memanfaatkan bahan baku } \\
\text { yang tersedia di dalam }\end{array}$ & 0.20 & 7 & 1.39 \\
\hline Total & 1.00 & 67.64 & 67.64 \\
\hline \multicolumn{4}{|l|}{ Kelemahan (W): } \\
\hline Belum memenuhi permintaan konsumen dengan tepat & 0.05 & 6.66 & 0.35 \\
\hline Kemasan yang digunakan belum memiliki label dan tidak menarik & 0.09 & 3.66 & 0.32 \\
\hline Saluran Pemasaran belum maksimal & 0.09 & 4.66 & 0.43 \\
\hline $\begin{array}{l}\text { Jangkauan pemasaran hanya mencangkup pada pedagang pengumpul } \\
\text { (sangat bergantung pada pedagang pengumpul) }\end{array}$ & 0.11 & 7 & 0.79 \\
\hline Petani aren hanya bergantung pada hasil penjualan gula aren & 0.11 & 6,33 & 0.69 \\
\hline Kurangnya pengetahuan dan wawasan SDM & 0.09 & 7 & 0.64 \\
\hline Masih menggunakan alat tradisonal dalam pembuatan gula aren & 0.10 & 9.33 & 0.94 \\
\hline Harga hanya dapat ditentukan oleh pedagang & 0.20 & 7 & 1.43 \\
\hline Proses produksi bergantung pada bahan baku yang tersedia dialam & 0.15 & 7 & 1.06 \\
\hline Total & 1.00 & 58.64 & 58.64 \\
\hline
\end{tabular}

Tabel 4. External Factors Analysis Summary (EFAS) 


\begin{tabular}{|c|c|c|c|}
\hline Faktor-faktor Strategi Eksternal & Bobot & Rating & Nilai Skor \\
\hline \multicolumn{4}{|l|}{ Peluang (O): } \\
\hline Tingkat konsumsi masyarakat terhadap produk meningkat & 0.05 & 9.33 & 0.47 \\
\hline $\begin{array}{l}\text { Masyarakat sadar akan pola hidup sehat dengan mengkonsumsi } \\
\text { produk gula aren berbahan alami }\end{array}$ & 0.08 & 9.33 & 0.79 \\
\hline $\begin{array}{l}\text { Berkembangnya teknologi komunikasi yang memudahkan dalam } \\
\text { melakukan kemitraan dan berkomunikasi }\end{array}$ & 0.10 & 7 & 0.67 \\
\hline $\begin{array}{l}\text { Kepuasan pelanggan terhadap produk akan menarik lebih banyak } \\
\text { pelanggan baru }\end{array}$ & 0.09 & 8.33 & 0.71 \\
\hline Permintaan konsumen terhadap gula aren yang semakin tinggi & 0.12 & 7 & 0.82 \\
\hline $\begin{array}{l}\text { Kebijakan pemerintah dalam melakukan peningkatan kapasitas } \\
\text { terhadap masyarakat pembuat gula aren }\end{array}$ & 0.10 & 7.33 & 0.76 \\
\hline Teknologi pengelolaan pasca panen cukup tersedia & 0.16 & 5.66 & 0.91 \\
\hline Adanya kebijakan pemerintah terkait kemitraan dengan kelompok tani & 0.13 & 7 & 0.90 \\
\hline $\begin{array}{l}\text { Penggunaan teknologi tepat guna untuk skala komersil dan teknologi } \\
\text { packing akan meningkatkan kualitas dan kuantitas produk gula aren }\end{array}$ & 0.17 & 7 & 1.21 \\
\hline Total: & 1.00 & 67.9849 & 30.00 \\
\hline \multicolumn{4}{|l|}{ Ancaman (T): } \\
\hline Masuknya pesaing baru & 0.05 & 4,66 & 0.25 \\
\hline Produk sejenis yang lebih bagus dan berkualitas & 0.09 & 7,33 & 0.67 \\
\hline $\begin{array}{l}\text { Mitra dapat beralih kepembuat gula aren yang lain dikarenakan } \\
\text { berkembangnya teknologi komunikasi }\end{array}$ & 0.11 & 8 & 0.90 \\
\hline Ketidakpuasan pelanggan terhadap hasil produksi & 0.09 & 4,66 & 0.40 \\
\hline Banyaknya pesaing & 0.12 & 4,33 & 0.53 \\
\hline $\begin{array}{l}\text { Tidak adanya peremajaan tanaman aren (petani hanya bergantung pada } \\
\text { tanaman aren yang tumbuh secara alami) }\end{array}$ & 0.10 & 4.66 & 0.46 \\
\hline Jumlah pesaing yang cukup tinggi & 0.14 & 4.66 & 0.66 \\
\hline Belum ada kemitraan dengan pemerintah setempat & 0.13 & 4.66 & 0.60 \\
\hline $\begin{array}{l}\text { Dengan menggunakan peralatan pendukung maka akan meningkatkan } \\
\text { biaya-biaya yang nantinya akan berpengaruh pada pendapatan }\end{array}$ & 0.16 & 6.66 & 1.08 \\
\hline Total & 1.00 & 49.62 & 49.62 \\
\hline
\end{tabular}

Berdasarkan hasil skoring dari IFAS dan EFAS, maka positioning quadrant usaha gula aren sebagaimana pada gambar 1. Nilai total kekuatan ialah 67.64 dikurangi dengan nilai total kelemahan ialah 58.64, maka nilai IFAS adalah 9.00. Sedangkan nilai EFAS dengan mengurangkan nilai total dari peluang ialah 67.94 dan nilai total ancaman ialah 49.64 maka didapatkan hasil untuk nilai EFAS yaitu 18.32. 


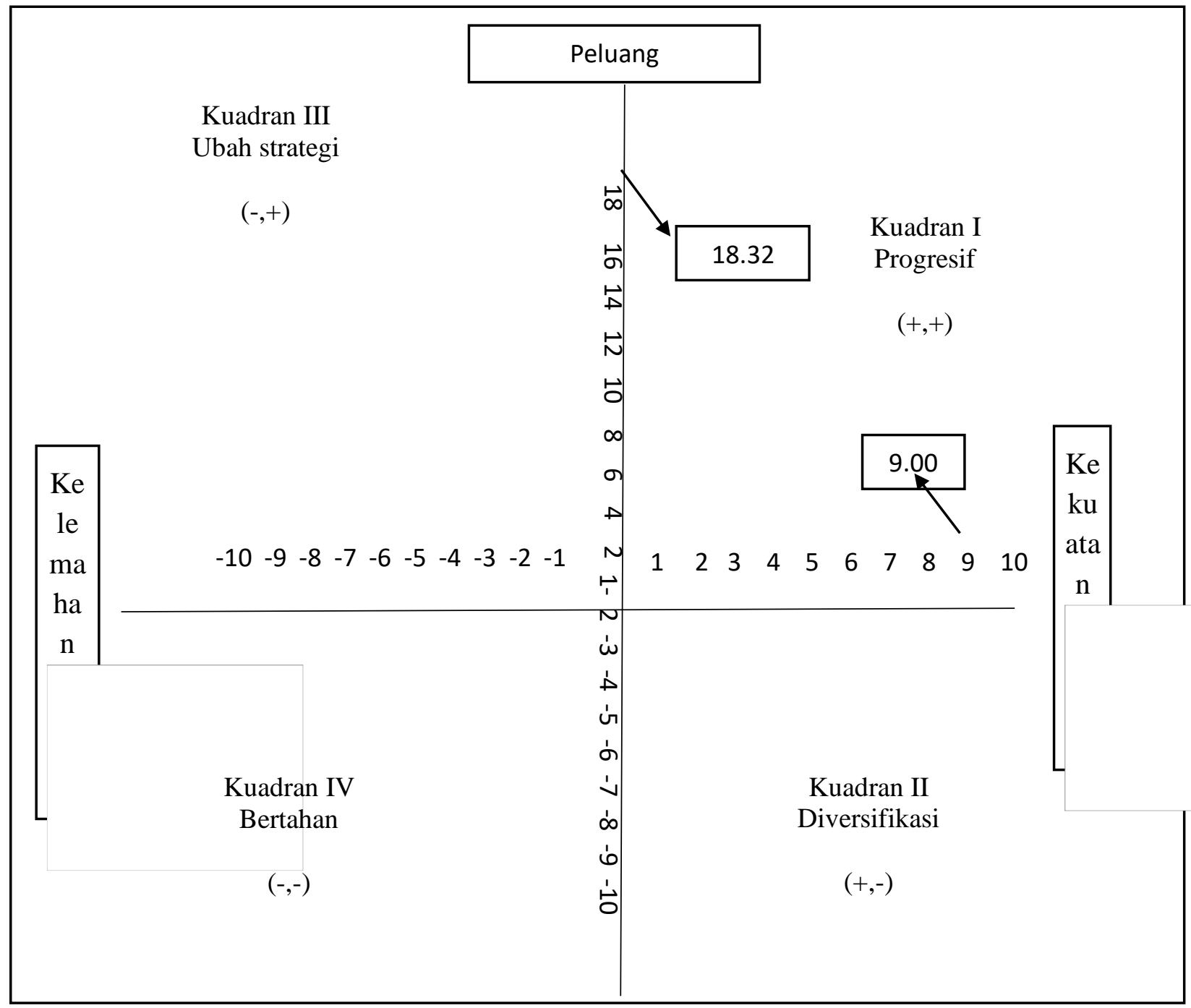

Gambar 1. Positioning quadrant usaha gula aren

Kelemahan yang dihadapi pembuat gula aren ialah dengan ukuran dari gula aren yang dihasilkan terlalu kecil maka membuat gula tersebut menjadi kurang menarik. Selain itu ketergantungan kepada pedagang pengumpul yang menjadikan akses pasar yang tersedia menjadi terbatas. Di sisi lain, peluang yang dihadapi pembuat gula aren ialah dengan tingginya kebutuhan masyarakat akan gula aren, karena semakin meningkatnya kesadaran masyarakat akan pola hidup sehat. Selain itu, dengan teknologi yang telah berkembang dengan baik mempermudah pembuat gula dalam berkomunikasi maupun dalam proses pengolahan gula aren. 
Gambar 1 menunjukkan posisi yakni kuadran I (progresif) yang bernilai positif (18.32) pada faktor eksternal dan 9,00 yang bernilai positif untuk faktor internal positif. Kondisi ini memberikan gambaran bahwa disisi eksternal kekuatan memiliki nilai sedikit lebih besar dibanding internal kelemahan yang ada. Namun pada sisi eksternal peluang yang dimiliki jauh lebih besar dibandingkan dengan ancaman yang ada, hal ini menunjukkan bahwa pilihan strategi yang tepat adalah dengan memanfaatkan kekuatan yang ada untuk meraih peluang.

\section{Bussines Model Canvas Ideal}

Berdasarkan dari hasil yang telah didapatkan sebelumnya, hal ini menunjukkan bahwa pilihan strategi yang tepat adalah dengan memanfaatkan kekuatan yang ada untuk meraih peluang. BMC merupakan gambaran, visualisasi, penilaian serta menyesuaikan model bisnis berdasarkan kondisi riil suatu organisasi (Osterwalder \& Pigneur, 2015). Adapun model dari BMC yang baru atau yang ideal yang disarankan dapat dilihat pada Gambar 2.

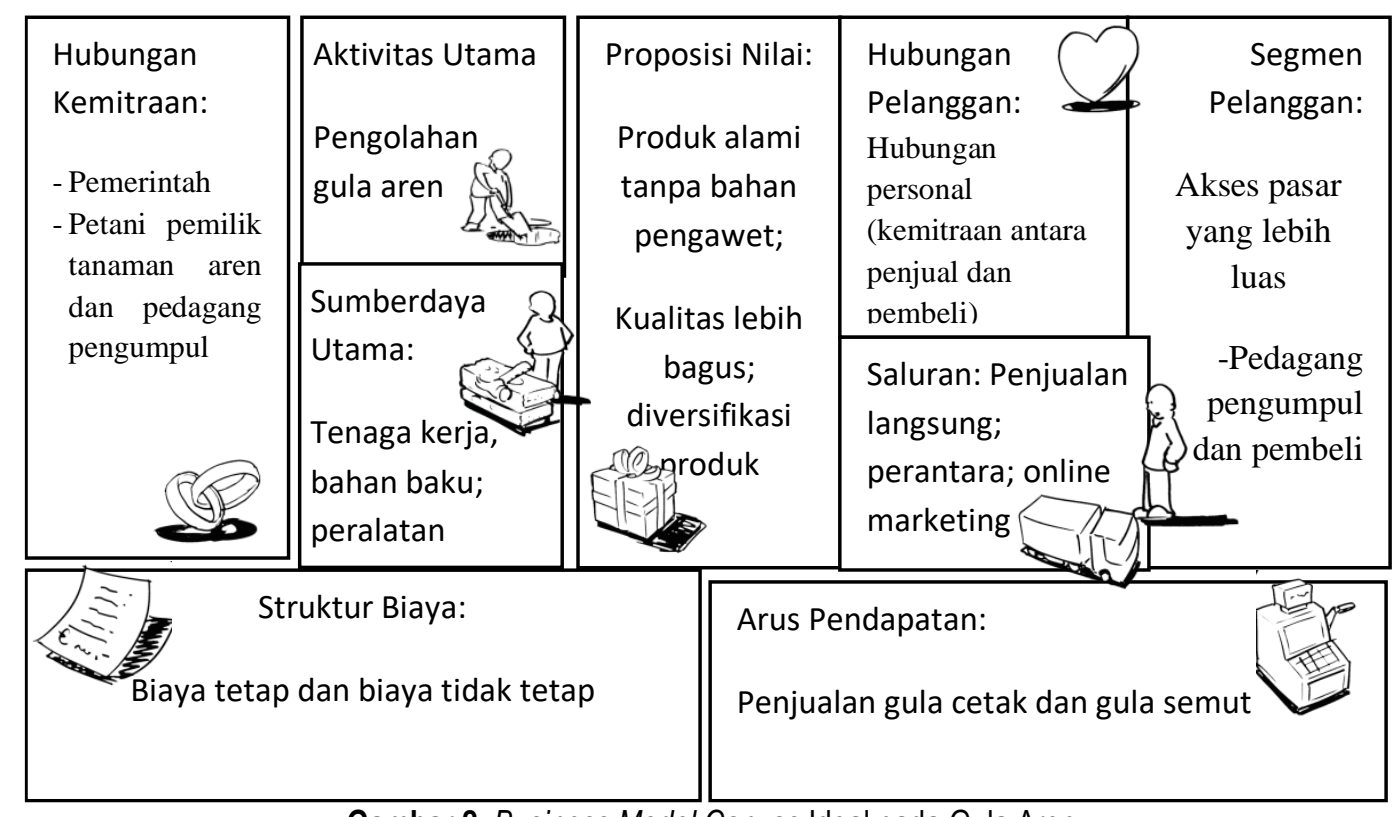

Gambar 2. Business Model Canvas Ideal pada Gula Aren.

Pada unit usaha gula aren ini, segmentasi pelanggan tetap sama dengan eksisting modelnya, hanya saja ditambahkan dengan akses pasar yang lebih luas. Akses pasar yang lebih luas disini adalah pembuat gula aren menjual gula aren mereka pada konsumen yang lebih banyak lagi. Sedangkan proposisi nilai pada usaha gula aren ini, 
proposisi nilai yang ditambahkan ialah dengan merubah kualitas dari gula aren baik dari segi bentuk, rasa, dan kemasan. Selain itu, pembuatan produk baru juga dapat dilaksanakan dengan membuat gula semut sebagai produk baru yang dipasarkan pembuat gula aren tersebut.

Saluran dalam usaha gula aren ada dua macam yaitu melalui pedagang pemgumpul (indirect selling) dan penjualan langsung ke pasar (direct selling) yang dilakukan oleh pembuat gula aren. Selain itu juga dilakukan penjualan secara online (online marketing) untuk memperbesar peluang usaha dari gula aren tersebut. Hubungan pelanggan yang di bangun dalam usaha gula aren adalah hubugan personal antara penjual dan pembeli dalam hal ini antara pedagang pengumpul dan pembeli langsung. Hubungan personal yang terjalin berupa komitmen antara pembuat gula aren dan para pelanggannya, sehingga tidak dikhawatirkan lagi atas ketidak loyalan dari para konsumen tersebut.

Pendapatan diperoleh dari penjualan langsung ke pedagang pengumpul dan penjualan langsung kepasar. Pendapatan yang diperoleh berupa hasil jual produk aren ke pedagang pengumpul yang dijual secara langsung. Sumberdaya utama yang terdapat pada usaha gula aren ini terdiri atas, tanaman aren, peralatan kerja, tenaga kerja yang memiliki skill, serta teknologi yang memadai. Aktivitas utama yang dilakukan oleh pembuat gula aren adalah memproduksi produk gula aren berupa gula cetak. Kemitraan yang terbangun dalam usaha gula aren ini adalah kemitraan dengan pemerintah dalam rangka pelatihan yang mendukung usaha gula aren yang ada. Selain itu, hubungan pembeli-pemasok untuk menjamin pasokan yang dapat diandalkan. Kemitraan didalam pemanfaatan tanaman aren yang ada di arealnya dengan pembuat gula aren. Struktur biaya yang dikeluarkan oleh usaha gula aren tidak berubah dari kondisi sebelumnya yakni (cost driven) karena biaya yang dikeluarkan tergolong sedikit.

\section{KESIMPULAN DAN SARAN}

Usaha ini masih mempertahankan segmentasi pasar yang sama sejak lama karena proses pejualan hanya bergantung pada konsumen dan pedagang pengumpul tanpa adanya upaya untuk mendapatkan pelanggan baru seperti mempromosikan melalui media. Faktor kekuatan (Strengths) mempunyai nilai skor 67.64 sedangkan faktor-faktor 
kelemahan (weaknesses) mempunyai nilai skor 58.64. Selain itu, faktor-faktor peluang (Opportunities) mempunyai skor 30.00 dan faktor-faktor ancaman (threats) mempunyai nilai skor 49.62, hal ini berarti bahwa dalam upaya menentukan strategi usaha gula aren ini mempunyai peluang yang sedikit rendah dibandingkan ancaman yang akan timbul.

Pilihan Strategi yang tepat pada usaha gula aren ini adalah mengoptimalkan kekuatan untuk meraih sebuah peluang atau turn around, mengubah strategi dalam pengembangan usaha gula aren yang ada di Desa Mattabulu, Kecamatan Lalabata, Kabupaten Soppeng, dimana usaha ini harus menangkap peluang pasar dengan meningkatkan nilai proposisinya, menjalin kemitraan dengan pemilik pemerintah dan memperluas jaringan pasar

\section{DAFTAR PUSTAKA}

Daft, R.L.2010. Era Baru Manajemen Edisi 9. Salemba Empat. Jakarta.

Dianpratiwi, T., Permashi, D., Putra L.K. 2020. Analisis Kinerja dan Prospek Komoditas Gula. Radar Opini dan Analisis Perkebunan, Vo. 1 (1): 1-10

Fahmi, I., 2013. Manajemen Strategis. Alfabeta. Bandung.

Gurel, E., Merba, T.A.T. (2017). SWOT Analysis: A Theoretical Review. The Journal of International Social Research, Vol.10 (51): 1-13

Haris., S.W., Ridwan., Makkarennu. 2020. Analisis Pendapatan Usaha gula Aren di Desa Gantarang, Kabupaten Sinjai Sulawesi Selatan. Perennial, Vol. 16 (1): 18 25

Kementerian Pertanian, 2019. Buku Outlook Komoditas Perkebunan Tebu. Pusat Data dan Sistem Informasi Pertanian Sekretariat Jenderal-Kementerian Pertanian. Jakarta

Lempang, M. (2012). Pohon Aren dan Manfaat Produksinya, Info teknis eboni vol.9 no.1, 37-54

Makkarennu, Rizaldy, A.A., Mahbub, A.S. (2019). Marketing Strategic and Competitive Positioning of Palm Sugar Business development. IOP Conf. Series: Earth and Environmental Science 270 (2019) 012029 
Mariati, R. (2013). Potensi produksi dan prospek pengembangan tumbuhan aren (Arenga Pinnata) di Kalimantan Timur. Jurnal Agrifor (12), 2-10

Mokuna, A.C., Makkarennu., Ridwan. 2017. Sistem Pemasaran Gula Semut Kelompok Tani (KTH) Buhung Lali pada Hutan Kemasyarakatan (HKm) Bangkeng Bukit di Desa Bukit Harapan Kecamatan Gantarang, Kabupaten Bulukumba. Jurnak Hutran dan Masyarakat, Vol. 9 (2): 83-92

Osterwalder, A. dan Pigneur Y.2015. Business Model Generation. PT Elex Media Komputindo. Jakarta.

Pohan, R.M., Purwoko, A., dan Martial. 2014. Kontribusi Hasil Hutan Bukan Kayu dari Hutan Produksi Terbatas Bagi Pendapatan Rumah Tangga Masyarakat. Peronema Forestry Science Journal, 3 (20) : 1-9

Pontoh, J., dan Wuntu A. 2014. Perbaikan Proses Pembuatan Gula Merah Aren di Pabrik Gula Aren Masarang Tomohon. Jurnal MIPA Universitas Sam Ratulangi Online 3(2). Manado.

Pontoh, J. 2013. Penentuan Kandungan Sukrosa Pada Gula Aren Dengan Metode Enzimatik. Chem.Prog. 6(1). Manado.

Rangkuti, F. 2016 . Analisis SWOT Balance Scorecard. PT Gramedia Pustaka Utama. Jakarta.

Soekarto, Soewarno, Hanny W.,Agus S., dan Soesarsono W.2010. Kajian Beberapa Jenis Penggunan Gula Merah Untuk Industri dan Pengolahan Pangan di Indonesia. Repository IPB. Bul.Pen. Ilmu dan Tek. Pangan 1 (53). Bogor. 